\title{
Pengaruh JUB, Suku Bunga, Inflasi, Ekspor dan Impor terhadap Nilai Tukar Rupiah atas Dollar Amerika Serikat
}

\author{
The Impact of Money Supply, Interst Rate, Inflation, Export and Import on \\ Exchange Rate Rupiah to U.S Dollar
}

\author{
Nurul Hazizah, Zainuri ${ }^{1}$, Sebastiana Viphindrartin \\ Jurusan Ekonomi Pembangunan, Fakultas Ekonomi dan Bisnis Universitas Jember \\ Jalan Kalimantan 37, Jember 68121 \\ E-mail:aznrjbr@gmail.com
}

\begin{abstract}
Abstrak
Fluktuasi nilai tukar rupiah terhadap Dolar Amerika Serikat yang tidak stabil dipengaruhi oleh kondisi ekonomi dalam negeri dan luar negeri. Kondisi makroekonomi kedua Negara baik Indonesia dan Amerika Serikat dapat menjadikan nilai tukar terdepresiasi atau terapresiasi. Tujuan penelitian ini adalah untuk mengetahui pengaruh selisih variabel makro kedua Negara yaitu Indonesia dan Amerika Serikat terhadap besarnya nilai tukar Rupiah atas Dolar Amerika. Model dalam penelitian ini adalah model dinamis yaitu Parsial adjustment Model (PAM) dimana model ini dianggap ada variabel kelambanan yaitu besarnya nilai tukar yang diharapkan dipengaruhi oleh nilai tukar yang terjadi sebelumnya. Terdapat dua analisis yaitu analisis deskriptif dan analisis kausal. Analisis kausal dengan menggunakan metode Oldinary Least Square (OLS). Estimasi OLS dalam PAM menunjukan seluruh variabel independen berpengaruh positif terhadap besarnya nilai tukar yang diharapkan selain variabel selisih Ekspor, selain itu variabel selisih suku bunga tidak berpengaruh signifikan terhadap besarnya nilai tukar yang diharapkan. Sehingga dapat disimpulkan bahwa kebijakan suku bunga dianggap dapat mempengaruhi besarnya exchange rate rupiah apabila kedua Negara tidak merubah besarnya suku bunga secara bersamaan dan kebijakan variabel makro lainnya harus menyesuaikan.
\end{abstract}

Kata kunci: Selisih variabel makro, Parsial Ajustment Model (PAM), Analisis Kausal, Exchange Rate

\begin{abstract}
Fluctuations of exchange rate against Rupiah to U.S Dollar which unstable are influenced the domestic and foreign's economic conditions. Macroeconomic conditions in the two countries both Indonesia and United States can make the exchange rate depreciate or appreciate. The purpose of this research is to acknowledge the difference impact macro variables in both countries Indonesia and the United States against the value on rupiah to US Dollar. Dynamic model is applied in this research that is Partial Adjustment Model (PAM). This model is considered to existing inertia variable that is expectation of exchange rate influence by the value of exchange rate that occurred previously. There are two analysis is descriptive analysis and causal analysis. Causal is using Ordinary Least Square (OLS) method. OLS estimation of PAM shows all independent variable have positive impact to the exchange rate expectation besides difference Export variable, in addition the difference of the interest rate variable can't influence the exchange rate significantly on important of the exchange rate expectation. In conclusion, the interest rate policy is considered to influence the rupiah exchange rate if two countries do not change the interest rate simultaneously and other macro policy variables must bring into line.
\end{abstract}

Keywords: Difference macro variables, Partial Adjustment Model (PAM), Causal Analysis, Exchange Rate

\section{Pendahuluan}

Keterbukaan perekonomian menimbullkan kekawatiran tersendiri bagi setiap negara. Hal itu disebabkan oleh arus globalisasi dan liberalisasi yang juga akan membawa konsekuensi pada fundamental perekonomian masing-masing negara. Ketidakmampuan negara dalam menjaga fundamental perekonomian akan membawa dampak ketidakstabilan ekonomi makro suatu negara (Muklis, 2013). Keterbukaan tersebut juga mengakibatkan suatu negara melakukan perdagangan Internasioanal dimana harga dijadikan acuan. Setiap negara untuk menunjukan harga diperlukan mata uang yang harus menyesuaikan dengan mata uang negara lain atau negara partner. Hal tersebut disebut sebagai kurs dimana kurs dianggap memainkan peranan sentral dalam perdagangan internasional dimana kurs dapat menggabarkan harga-harga barang dan jasa yang dihasilkan negara tersebut (Krugman dan Obsfeld, 1999:41)

Menurut Chou (2000) mengatakan bahwa kondisi naik turunnya nilai tukar menunjukkan besarnya volatilitas dimana volatilitas yang semakin besar menunjukan pergerakan kurs semakin besar yaitu terjadinya apresiasi/depresiasi. Kondisi tersebut dipengaruhi oleh faktor ekonomi maupun non

1 Corresponding Author 
ekonomi baik domestik maupun luar negeri. Faktor-faktor tersebut berupa juga faktor fundamental, faktor teknis, dan faktor sentimen pasar.

Berbagai teori yang menjelaskan besarnya nilai tukar mata uang yang dipengaruhi oleh variabel makro ekonomi seperti tingkat suku bunga dapat dijelaskan dengan purchasing power parity theory (PPP) atau disebut teory paritas daya beli. PPP absolut menyatakan bahwa harga suatu barang atau produk yang sama di dua Negara yang berbeda akan sama pula dinilai dalam mata uang yang sama. Versi relatif muncul karena terdapat kelemahan-kelemahan terhadap versi absolut dimana versi relatif mengubah pernyataan tingkat harga dan tingkat kurs keseimbangan menjadi perubahan harga dan perubahan kurs keseimbangan (Salvatore dalam Agustin, 2009). Sedangkan hubungan kurs dengan suku bunga digambarkan oleh teori Interest rate parity/paritas suku bunga dimana teori ini menyatakan bahwa kurs dapat ditentukan apabila terdapat tingkat bunga antara dua Negara. Kondisi paritas suku bunga terjadi ketika kekuatan pasar memaksa perubahan suku bunga dan kurs sedemikian rupa sehingga dapat menjamin perlindungan untuk tetap dalam keimbangan meskipun di masa mendatang (Nurqoidoh, 2010).

Beberapa studi mengenai korelasi antara tingkat bunga, inflasi dan nilai tukar tidaklah signifikan, karena dipengaruhi secara simultan oleh kejadian baru dan dinformasi yang sama. Hal itu sesuai dengan pernyataan Noor (2011) setiap kali ada perubahan yang terjadi akan selalu diikuti oleh penyesuaianpenyesuaian yang akan dilakukan. Studi lain mengenai perilaku pembentukan nilai tukar banyak dilakukan di beberapa Negara dengan pendekatan ekonometrik dan data agregat. Berdasarkan beberapa penelitian indicator ekonomi yang sering digunakan dalam mengetahui pergerakan nilai tukar adalah tingkat inflasi, tingkat suku bunga dan Jumlah uang yang beredar. Tingkat inflasi mempengaruhi nilai tukar mata uang pada pasar uang. Hal itu sesaui dengan penelitian Achsani et.al (dalam Noor, 2011) yang menunjukan bahwa di Negara Asia inflasi mempunyia pengaruh yang signifikan terhadap nilai tukar segitu juga dengan tingkat suku bunga dan money supply.

Berdasarkan fenomena di atas perlu dilakukan telaah lebih lanjut mengenai pengaruh beberapa variabel makroekonomi yaitu suku bunga, inflasi dan jumlah uang beredar, ekspor dan impor terhadap nilai tukar rupiah atas Dolar Amerika yang dilihat dengan menggunakan selisih variabel makro antara Indonesia dan Amerika dan dikaji dengan beberapa teori-teori yang mendasari tentang pergerakan nilai tukar rupiah.

\section{Metode}

\section{Rancangan atau Desain Penelitian}

Metode analisis dalam menjawab pertanyaan empiris terdiri dari dua metode analisis yaitu metode analisis statistik deskriptif naratif dan metode analisis kausal. Metode analisis kausal menggunakan data runtun waktu dengan menggunakan model dinamis Parsial Adjustment Model (PAM) dan metode estimasi berupa Ordinary Least Square (OLS) serta uji asumsi klasik dan asumsi statistik

\section{Jenis dan Sumber Data}

Jenis data yang digunakan dalam penelitian ini adalah jenis data sekunder berupa data runtun waktu (time series) berupa data triwulan dimulai dari 2005Q.3-2013Q.4. Sedangkan objek penelitian Indoenesia dan Amerika Serikat. Data yang digunakan dalam penelitian bersumber dari publikasi situs resmi dari Bank Indonesia (BI), Badan Pusat Statistik (BPS), World Economic Outlook (WEO), Federal Reserver (The Fed), Word Bank, Bloomberg dan beberapa literatur terkait.

\section{Spesifikasi Model Penelitian}

Model dalam penelitian ini diadapsi dari penelitian yang dikembangkan oleh Pratiwi dan Santoso (2012), Indrawanti dan Nurmiati (2006) dan Noor (2012). Peneliti tersebut menggunakan model regresi linier berganda dan Parsial Adjustment Model. Model dapat dibentuk dengan runtutan persamaan sebagai berikut:

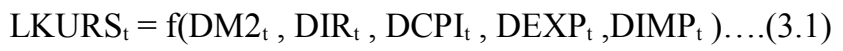

Kemudian model tersebut ditranformasikan ke dalam model ekonometrika yang merupakan bentuk umum regresi dengan model OLS menjadi:

$$
\begin{aligned}
\text { LKURS }_{\mathrm{t}}= & \beta_{0}+\beta_{1} \mathrm{DM}_{2}+\beta_{2} \mathrm{DIR}_{\mathrm{t}}+\beta_{3} \mathrm{DCPI}_{\mathrm{t}}+\beta_{4} \mathrm{DEXP}_{\mathrm{t}}+ \\
& \beta_{5} \mathrm{DIMP}_{\mathrm{t}}+\mathrm{e}_{\mathrm{t}} \ldots \ldots \ldots \ldots \ldots \ldots \ldots \ldots \ldots \ldots \ldots \ldots \ldots \ldots \ldots \ldots \ldots \ldots \ldots \ldots \ldots \ldots \ldots \ldots \ldots \ldots \ldots \ldots \ldots \ldots \ldots \ldots \ldots \ldots \ldots \ldots \ldots \ldots
\end{aligned}
$$

Dengan menanggap bahwa untuk mengukur besarnya variabel dependen dipengaruhi oleh kelambanan dari variabel dependen tersebut pada periode sebelumnya atau disebut adanya beda kala/lag. Sehingga analisis variabel independen terhadap perubahan nilai tukar Rupiah terhadap Dollar pada penelitian ini yang diadapsi dari penelitian sebelumnya yang menggunakan model linier berganda dan model dinamis yaitu partial adjustment model yang ditunjukkan dalam jangka pendek menjadi:

$$
\begin{aligned}
\text { LKURS }_{\mathrm{t}}= & \beta_{0}+\beta_{1} \mathrm{DM}_{2}+\beta_{2} \mathrm{DIR}_{\mathrm{t}}+\beta_{3} \mathrm{DCPI}_{\mathrm{t}}+\beta_{4} \mathrm{DEXP}_{\mathrm{t}}+ \\
& \beta_{5} \mathrm{DIMP}_{\mathrm{t}}+\beta_{6} \mathrm{LKURS}_{\mathrm{t}-1}+\mathrm{e}_{\mathrm{t}} \ldots \ldots \ldots \ldots \ldots \ldots \ldots \ldots \ldots \ldots \ldots \ldots \ldots \ldots \ldots \ldots \ldots \ldots \ldots \ldots \ldots
\end{aligned}
$$

Keterangan:

LKURS $_{\mathrm{t}}=$ Kurs Rupiah (IDR) terhadap Dollar Amerika (USD)

$\mathrm{DM} 2_{\mathrm{t}}=$ Selisih jumlah uang yang beredar (M2) di Indonesia dan Amerika pada periode $\mathrm{t}$

DIR $_{\mathrm{t}}=$ Selisih BI Rate dan suku bunga US Prime Rate pada periode $\mathrm{t}$

DCPI $_{\mathrm{t}}=$ Selisih Inflasi inti Indonesia dan Amerika pada periode $\mathrm{t}$

$\operatorname{DEXP}_{\mathrm{t}}=$ Selisi Ekspor Indonesia dan Amerika pada periode $\mathrm{t}$

DIMP $_{t}=$ Selisi Impor Indonesia dan Amerika pada periode $\mathrm{t}$

LKURS $_{\mathrm{t}-1}=$ Perubahan Kurs pada periode sebelumnya

$\mathrm{L}=$ Logaritma

$\beta=$ Koefisien parameter

$\beta_{6} /(-\delta) \quad=$ Koefisien penyesuaian

$\mathrm{e}_{\mathrm{t}}$.

Error term

Selanjutnya untuk mengestimasi koefisien jangka panjang dapat ditentukan oleh koefisen jangka pendek. Berdasarkan Kuspriyadi (2004) untuk mengetahui koefisien jangka panjang dapat dihitung berdasarkan koefisien jangka pendek 
dengan rumus sebagai berikut: $\delta_{0}=\beta_{0} / 1-\beta_{6}$ dan seterusnya mengikuti koefisien tiang variabelnya.

\section{Metode Analisis Data}

Penelitian ini berfokus pada dua metode yaitu metode analisis deskriptif dan kausal/kuantitatif. Analisis deskriptif untuk menjelaskan tentang objek penelitian secara komprehensif yaitu mengenai fenomena-fenomena yang berkaitan dengan masalah yang diteliti. Sedangkan analisis kausal untuk menganalisis masalah secara kuantitatif yaitu menggambarkan pengaruh variabel bebas (independen) terhadap variabel terikat (dependen) dengan menggunakan metode analisis data.

Model Parsial Adjustmen Model (PAM) dapat diestimasi menggunakan metode Ordinary Least Square (OLS) atau metode kuadrat terkecil merupakan metode kuantitatif yang digunakan untuk mencari nilai residual terkecil mungkin dalam mengetahui pengaruh masing-masing variabel independen terhadap variabel dependen Madjid (dalam Magfiroh, 2013).

\section{Hasil dan Pembahasan}

\section{Hasil Analisis Deskriptif}

Analisis statistik deskriptif menunjukkan perilaku tiap independen dalam mempengaruhi variabel terikat (dependen). Variabel terikat dalam penelitian ini adalah besarnya nilia tukar rupiah terhadap Dolar Amerika sedangkan variabel independennya terdiri dari selisih JUB, selisih suku bunga, selisih inflasi, selisih ekspor dan selisih impor antara Indonesia dan Amerika Serikat serta ada tambahan variabel independen yaitu besarnya nilai tukar periode sebelumnya. Hasil analisis statistik tersebut dapat terlihat pada tabel berikut ini:

Tabel 1. Nilai Mean, Median, Maximum, Minimum, Standard Deviasi dari Masing-masing Variabel LKURSLDM2 DIR DCPI DEXP DIMP LKUS(-1)

\begin{tabular}{cccccccc} 
Mean & 3,98 & 12,49 & 6,15 & 5,11 & 3,58 & 7,71 & 3,97 \\
$\begin{array}{c}\text { Medi } \\
\text { an }\end{array}$ & 3,97 & 12,51 & 6,25 & 4,16 & 3,92 & 5,47 & 3,96 \\
$\begin{array}{c}\text { Maxi } \\
\text { mum }\end{array}$ & 4,07 & 12,57 & 9,5 & 13,78 & 24,69 & 36,99 & 4,06 \\
$\begin{array}{c}\text { Mini } \\
\text { mum }\end{array}$ & 3,93 & 12,38 & 3,25 & 0,02 & $-13,9$ & $-15,6$ & 3,93 \\
$\begin{array}{c}\text { Std. } \\
\text { Dev. }\end{array}$ & 0,03 & 0,05 & 1,43 & 3,63 & 9,53 & 14,32 & 0,03 \\
\begin{tabular}{c} 
Obs. \\
\hline
\end{tabular} & 33 & 33 & 33 & 33 & 33 & 33 & 33 \\
\hline
\end{tabular}

Sumber: World Bank dan Bank Indonesia, diolah

Tabel diatas menunjukkan adanya daya saing dan persebaran masing-masing variabel. Daya saing yang baik terlihat pada interval antara nilai maksimum dan minimum yang jauh. Daya saing yang baik terdapat pada variabel selisih suku bunga, selisih Inflasi, selisih ekspor dan variabel yang mempunyai daya saing yang tinggi adalah selisih impor antara Indonesia dan Amerika yang nilai maksimumnya sebesar 36.99000 dan nilai minimum hingga -15.60000. Variabel lain dianggap mempunyai daya saing yang cukup karena interval nilai maksimum dan minimum yang tidak jauh yang berarti tidak begitu berfluktuatif. Interval yang jauh pada variabel diatas yang berarti bahwa variabel dapat memberikan gambaran kondisi ekonomi melalui variabel tersebut sehingga dapat berkontribusi dalam perdagangan internasional baik melalui transaksi barang dan jasa yang dilakukan kedua Negara.

Hasil estimasi diatas juga menjelaskan tentang gambaran persebaran data masing-masing variabel dalam penelitian yang terlihat dari standar deviasi dan nilai mean atau nilai rata-rata setiap variabelnya. Artinya persebaran data setiap variabel dapat dilihat dengan perbandingan antara nilai standart deviasi dan nilai mean variabel tersebut. Gambaran data nilai tukar memiliki persebaran data yang baik terlihat dari nilai standar deviasi yang lebih kecil yaitu sebesar 0.035618 dibandingkan dengan nilai mean nilai tukar sebesar 3.978609. Hal serupa juga terjadi pada beberapa variabel lain yang memilik persebaran data yang baik yaitu variabel selisih jumlah uang beredar, selisih inflasi, selisih suku bunga dan nilai tukar rupiah terhadap Dollar pada periode sebelumnya. Sedangkan kondisi sebaliknya terjadi pada variabel selisih ekspor Indonesia dan Amerika yang memiliki persebaran data yang tidak baik terlihat hasil estimasi yaitu nilai standar deviasi 3.583333 lebih besar dari nilai rata-rata 7.718485 dan variabel selisih impor Indonesia dan Amerika dengan hasil estimasi standar deviasi 9.535932 lebih besar dibandingkan nilai rata rata 14.32573 .

\section{Analisis Estimasi Ordinary Least Square pada PAM}

Partial Adjustment Model (PAM) adalah model linier dinamis yang dapat mengambarkan adanya variabel kelambaan sehingga terdapat koefisien penyesuaian dalam persamaannya. Metode Ordinary Least Square (OLS) dapat digunakan untuk mengestimasi PAM karena dianggap dapat melihat kemungkinan adanya hubungan keseimbangan jangka pendek dan mendukung adaya hubungan jangka panjang yaitu mengetahui hubungan pengaruh dari variabel independen terhadap variabel dependen. Metode estimasi OLS pada Parsial Adjustment Model ini tujuannya adalah mengetahui hubungan variabel makro ekonomi yang di hitung dengan selisih variabel kedua Negara terhadap nilai tukar dan dipengaruhi variabel kelambanan. Selisih variabel yang dimaksud adalah variabel selisih jumlah uang beredar, selisih suku bunga, selisih inflasi, selisih ekspor dan selisih impor Indonesia dan Amerika Serikat. Hasil estimasi Ordinary Least Square (OLS) dapat disajikan dalam Tabel 2.

Hasil estimasi menunjukkan bahwa Secara parsial pengaruh masing-masing variabel independen terhadap variabel dependen dikatakan signifikan jika probabilitas variabel lebih kecil dibandingkan nilai $\alpha(\alpha=5 \%=0,05)$. Hasil output regresi menunjukkan bahwa variabel perbedaan Money supply (M2) antara Indonesia dan Amerika berpengaruh positif dan signifikan terhadap besarnya perubahan nilai tukar Rupiah atas Dolar dengan melihat nilai koefisiennya sebesar 0,274586 dan nilai probabilitas sebesar 0.0160 dimana perbedaan money supply antara Indonesia dan Amerika akan menyebabkan perubahan nilai tukar sebesar 0,274586 artinya apabila variabel independen lainnya konstan maka setiap kenaikan perbedaan money supply sebesar 1 persen akan menaikkan nilai tukar Rupih terhadap Dollar Amerika (terdepresiasi) sebesar 0,274586. Pengaruh positif dan 
signifikan juga terjadi pada variabel perbedaan Inflasi dengan koefisien sebesar 0.0043800 dan perbedaan Impor dengan koefisiennya sebesar 000657. Artinya perbedaan kedua variabel akan menyebabkan perubahan nilai tukar yaitu mengalami depresiasi sebesar koefisien masing-masing variabel. Arah yang sama juga terdapat pada variabel kurs pada periode sebelumnya dimana dengan koefisien 0.692777 dan probabilitasnya sebesar 0.0349 sehingga diartikan bahwa variabel ini bepengaruh positif dan signifikan terhadap perubahan kurs Rupiah terhadap Dollar dilihat dari tanda positif dalam koefisiennya dan probabilitas yang lebih kecil dibandingkan tingkat $\alpha$.

Tabel 2. Hasil Estimasi Metode Ordinary Least Square (OLS)

\begin{tabular}{lrrr}
\hline \multicolumn{1}{c}{ Variabel } & Koefisien & t-statistic & Probabilitas \\
C & $-2,233750$ & $-1,622656$ & 0,1167 \\
LDM2 & 0,274586 & 2,576436 & 0,0160 \\
DIR & 0.000329 & 0,016000 & 0,9393 \\
DCPI & 0.004380 & 2,369054 & 0.0255 \\
DEXP & -0.001126 & -0.001126 & 0.0310 \\
DIMP & 0.000657 & 2.225943 & 0.0349 \\
LKURS(-1) & 0.692777 & 5.775288 & 0,0000 \\
R-square & 0,814574 & & \\
Adjusted R-square & 0.771784 & & \\
Durbin Waston & 1.556966 & & \\
Prob. F-hitung & 0.000000 & & \\
\hline
\end{tabular}

*) signifikan pada $\alpha=5 \%$.

Sumber: World Bank dan Bank Indonesia, diolah

Substituted Coefficients:

\section{LKURS $=-2.233750+0.274586 *$ LDM $2+0.000329 * \mathrm{DIR}+$ $0.004380 *$ DCPI $-0.001126 *$ DEXP $+0.000657 *$ DIMP + $0.692777 *$ LKURS $(-1)$}

Sedangkan variabel yang berpengaruh negatif dan signifikan terhadap besarnya kurs Rupiah atas Dollar Amerika adalah perbedaan ekspor Indonesia dan Amerika dengan nilai koefisien variabel sebesar -0.001126 dan probabilitasnya sebesar 0.0310, tanda negatif dari koefisien variabel menunjukkan bahwa pengaruh kedua varibel terbebut berlawanan arah, apabila perbedaan ekspor naik 1 persen maka rupiah akan apresiasi sebesar 0.001126 dan sebaliknya. Namun secara keseluruhan, keenam variabel tersebut berpengaruh signifikan terhadap besarnya nilai tukar rupiah terhadap dolar Amerika yang terlihat pada nilai probabilitas F-hitung yaitu 0.0000 yang menunjukkan nilai lebih kecil dari pada $\alpha(\alpha=5 \%=0.0500)$. Hasil estimasi juga menunjukkan bahwa nilai adjusted $\mathrm{R}^{2}$ sebesar 0.771784 yang menjelaskan bahwa seluruh variabel independen sebesar $77,17 \%$ memengaruhi besarnya nilai tukar rupiah terhadap Dolar Amerika serikat, sedangkan sisanya dipengaruhi oleh variabel lain di luar model tersebut

Sedangkan analisis koefisien jangka panjang dihasilkan dari nilai koefisien jangka pendek dari persamaan regresi yang dihasilkan diatas dengan rumus yang telah ditentukan dengan hasil sebagai berikut:

Tabel 3. Hasil Estimasi Parameter Pertumbuhan Jangka Panjang

\begin{tabular}{ccc} 
& $\begin{array}{c}\text { Koefisien Jangka } \\
\text { Pendek }\end{array}$ & $\begin{array}{c}\text { Koefisien Jangka } \\
\text { Panjang }\end{array}$ \\
C & $-2,233750$ & -7.270777 \\
LDM2 & 0,274586 & 0.8937677 \\
DIR & 0,000329 & 0.0010708 \\
DCPI & 0,004380 & 0.0142567 \\
DEXP & $-0,001126$ & -0.003665 \\
DIMP & 0.000657 & 0.0021385 \\
\hline
\end{tabular}

Sumber: World Bank dan Bank Indonesia, diolah

Tabel diatas menggambarkan koefisien jangka panjang dari model PAM yang dijadikan penaksiran untuk mengamati seberapa besar pengaruh variabel independen terhadap variabel dependen. Koefisien jangka panjang model PAM berturut-turut pada variabel selisih M2, Selisih suku Bunga, selisih inflasi, selisih ekspor dan selisih impor antara Indonesia dan Amerika yang diperolah dari koefisien jangka pendek dibagi 1- koefisien penyesuaian adalah: 0.8937677 , $0.0010708,0.0142567,-0.003665$, dan 0.0021385. Sehingga persamaan nilai tukar rupiah terhadap Dolar menjadi:

$$
\begin{aligned}
& \text { LKURS }=-7.270777+0.8937677 \text { LDM } 2+0.0010708 \text { DIR } \\
& \quad+0.0142567 \text { DCPI }-0.003665 \text { DEXP }+0.0021385 \text { DIMP }
\end{aligned}
$$

Persamaan tersebut dapat menafsirkan pengaruh variabel independen terhadap variabel dependen dalam jangka panjang dengan diketahui koefisien setiap variabel independen. Hal ini juga menunjukan bahwa pendekatan model dinamis dalam penelitian telah memenuhi kriteria yang ditentukan yaitu nilai kelambanan dari variabel dependen terletak diantara nilai nol dan satu.

\section{Hasil Uji Asumsi Klasik}

Pendugaan estimator dalam menganalisis variabel dalam model yang menggunakan metode Oldinary Least Square (OLS) masih belum dapat menggambarkan model penelitiana dan belum memenuhi syarat ekonomometrika. Metode OLS menganjurkan untuk tidak menyimpang dari asumsi BLUE (Best, Linier, Unibased, Estimator) dimana asumsi ini dapat terpenuhi melauli uji asumsi klasik yang menjadikan model dikatakan baik. Selain itu penggunaan model dinamis PAM dianggap menghasilkan nilai perameter penduga yang sah apabila telah dipenuhi asumsi klasik. Hasil pengujian terhadap asumsi klasik dengan bantuan program Eview 7.1 dapat digambarkan pada tabel sebagai berikut:

Tabel 4. Hasil Uji Asumsi Klasik

\begin{tabular}{ccccc}
\hline $\begin{array}{c}\text { Uji } \\
\text { Diagnosis }\end{array}$ & Test & $\begin{array}{c}\text { Output } \\
\text { Hitung }\end{array}$ & $\begin{array}{c}\text { Probabilita } \\
\mathbf{s}(\boldsymbol{\alpha}=\mathbf{5 \%})\end{array}$ & Kesimpulan \\
Autokorela & $\begin{array}{c}\text { Breucsh } \\
\text { si }\end{array}$ & 1.774587 & 0.1828 & Tidak Terdapat \\
Test & & & autokorelasi \\
\hline
\end{tabular}




\begin{tabular}{|c|c|c|c|c|}
\hline $\begin{array}{l}\text { Heterosked } \\
\text { astisitas }\end{array}$ & $\begin{array}{c}\text { White } \\
\text { Test } \\
\text { (with } \\
\text { Cross } \\
\text { Term) }\end{array}$ & 32.45218 & 0.1162 & $\begin{array}{l}\text { Tidak Terjadi } \\
\text { Heteroskedastis } \\
\text { itas }\end{array}$ \\
\hline $\begin{array}{l}\text { Multikoline } \\
\quad \text { aritas }\end{array}$ & $\begin{array}{l}\text { Correlati } \\
\text { on Matrix }\end{array}$ & - & - & $\begin{array}{l}\text { Tidak terjadi } \\
\text { multikolinearita } \\
\text { s }\end{array}$ \\
\hline Linearitas & $\begin{array}{c}\text { Ramsey } \\
\text { Reset Test }\end{array}$ & 7.164302 & 0.0074 & Data tidak linier \\
\hline Normalitas & $\begin{array}{c}\text { Jarque- } \\
\text { Berra } \\
\text { Test }\end{array}$ & 3.454119 & 0.177806 & $\begin{array}{c}\text { Berdistribusi } \\
\text { normal }\end{array}$ \\
\hline
\end{tabular}

Sumber: World Bank dan Bank Indonesia, diolah

Tabel hasil estimasi diatas menunjukkan bahwa dalam pengujian kriteria asumsi klasik terdapat kriteria yang tidak terpenuhi yaitu uji linieritas sedangkan asumsi lain dapat terpenuhi. Hasil estimasi menunjukkan bahwa uji autokorelasi yang dilakukan dengan menggunakna Breusch-Godfrey Serial Correlation LM Tes pada derajat pertama dinyatakan lolos dari autokorelasi dimana hasil menunjukan bahwa nilai probabilitas $>\alpha(5 \%)$ yaitu sebesar 0.1828 , sehingga metode analisis linier dinamis dianggap efisien dalam penelitian. Estimasi juga menunjukan tidak adanya masalah ketidaksamaan varians dari residual pengamatan satu ke pengamatan lain pada model sehingga model bersifat homokedastisitas, hal itu terlihat dalam hasil uji heterokedastisitas yang menggunakan uji white heteroschedasticity dengan with cross term dimana nilai probabilitas Obs*R-squared lebih besar dari $\alpha(\alpha=5 \%)$ yaitu sebesar 0.1162 .

Hasil analisis juga menunjukkan bahwa variabel independen dapat menjelaskan variabel dependen karena antar variabel independen tidak terdapat korelasi atau hubungan antar variabel artinya model dinyatakan lolos dari multikolinieritas. Hal itu dapat terlihat dimana dengan melakukan estimasi correlation matrix yang batas terjadi korelasi antar variabel independen sebesar 0,80 menunjukan bahwa tidak terdapat korelasi antar variabel independen karena nilai korelasi dibawah nilai batas terjadinya korelasi, sehingga tidak terdapat hubungan yang linier dan dapat menjelaskna variabel dependen dalam model. Berbeda dengan hasil estimasi pengujian linieritas dimana dengan menggunakan uji Ramsey diagnose bahwa data tidak bersifat linier terlihat dari nilai probabilitas F-statistik $0.0074<\alpha(\alpha=5 \%)$ artinya variabel independen tidak mempunyai hubungan yang linier dengan semua variabel independen. Residual dalam model penelitian dapat dilihat dengan menggunakan uji normalitas yaitu Jarque-Bera test menunjukan bahwa nilai probabilitas Jarque-Bera lebih besar dibandingkan a yaitu sebesar 0.177806 artinya model berdistribusi normal.

\section{Diskusi Hasil Analisis Determinasi Nilai Tukar Rupiah Terhadap Dollar Amerika Serikat}

Hasil Analisis dengan menggunakan metode Oldinary Least Square (OLS) pada model dinamis Parsial Adjusment Model (PAM) yang telah dilakukan memberikan hasil tentang hubungan selisih money supply (M2), selisih suku bunga, selisih inflasi, selisih ekspor dan selisih impor antara Indonesia dan Amerika Serikat terhadap perilaku kurs Rupiah atas Dolar Amerika Serikat. Dikarenakan penelitian ini menggunakan model peneysuaian parsial dimana terjadi kelambanan dalam model sehingga terdapat variabel tambahan yaitu variabel nilai tukar Rupiah atas Dolar periode sebelumnya. Dikarenakan penelitian ini menggunakan model peneysuaian parsial dimana terjadi kelambanan dalam model sehingga terdapat variabel tambahan yaitu variabel nilai tukar Rupiah atas Dolar periode sebelumnya. Variabel ini merupakan variabel dependen yang dijadikan variabel independen. Artinya setiap perubahan nilai tukar yang terjadi akan dipengaruhi oleh nilai tukar sebelumnya. Keenam variabel Independen tersebut dianggap dapat mempengaruhi peruabahan nilia tukar Tupiah Terhadap Dolar AS. Dimana terdiri dari perbedaan variabel makro ekonomi, perbedaan variabel dalam neraca perdagangan serta variabel penyesuaian dependen. Model yang dikembangkan berasal dari model yang diadopsi dari penelitian Noor (2011), namun penelitian ini menambahkan variabel ekpor dan impor karena dianggap kedua variabel tersebut dapat signifikan mempengaruhi nilai tukar rupiah.

Hasil dari penggunaan metode OLS pada PAM dapat terlihat pengaruh baik dalam jangka pendek dan jangka panjang. Dimana koefisien jangka panjang didapat berdasarkan koefisien jangka pendek hal itu berarti penafsiran jangka panjang diperoleh dari koefisien jangka pendek dalam sebuah model. Berdasarkan hasil analisis yang dilakukan secara simultas pengaruh variabel independen terhadap variabel dependen yaitu berpengaruh signifikan terhadap pergerakan nilai tukar Rupiah atas Dollar Amerika Serikat dalam jangka pendek terlihat dari nilai probabilitas F-statistik. Namun secara parsial mempunyai pengaruh yang salah satu variabel tidak signifikan terhadap besarnya nilai tukar rupiah terhadap Dollar Amerika.

Secara Parsial baik dalam jangka pendek maupun jangka panjang perilaku setiap variabel memiliki pengaruh yang fluktuatif. Perbedaan jumlah uang beredar dalam arti luas antara Indonesia dan Amerika Serikat berpengaruh positif dan signifikan terhadap perubahan nilai tukar Rupiah terhadap Dollar Amerika Serikat. Hal itu berarti bahwa setiap penambahan jumlah uang domestik akan mengakibatkan terdepresiasi atau supply rupiah naik. Apabila pemerintah menambah jumlah uangnya masyarakat akan masyarakat akan membelanjakan uangnya untuk konsumsi dan mengakibatkan harga-harga akan naik atau terjadi inflas domestik sehingga penawaran uang rupiah meningkat. Selain itu jika pemerintah menambah uang beredarnya akan menurunkan suku bunga sehingga dapat merangsang investor untuk berinvestasi keluar negeri yang mengakibatkan terjadi aliran dana keluar dan kurs akan terdepresiasi. Hal ini sesuai dengan pernyataan Krugman (2003:111) dimana kenaikan penawaran uang akan menurunkan suku bunga domestik dan mendorong mata uang dometik terdepresiasi. Hasil tersebut sejalan dengan penelitian yang dilakukan oleh Kholidin (2002), Atmadja (2002), Pratiwi (2012) dan Oktavia et.al (2013) yang menyatakan bahwa jumlah uang mempunyai pengaruh positif dan signifikan terhadap kurs Rupiah. Sehingga dapat diartikan bahwa jumlah uang beredar sacar relatif mempengaruhi nilai tukar rupiah dimana suatu mata uang akan berkurang nilainya 
jika jumlah uang beredar dikeluarkan lebih banyak.

Terdapat satu variabel yang berpengaruh tidak signifikan namun arah positif dalam model yaitu tingkat suku bunga hal itu ditandai dengan nilai probablitas variabel yang lebih besar dari tingkat kesalahan yaitu 0,05 . Hal itu dikarenakan tingkat bunga kedua Negara selama kurun waktu 2005-2013 mengalami fluktuasi yang sedikit sehingga meskipun bank sentral menaikan ataupun menurunkan suku bunga belum tentu akan mempengaruhi nilai tukar. Bank sentral masingmasing Negara yaitu Bank Indonesia dan The Fed tidak mudah untuk mengeluarkan kebijakan tentang perubahan tingkat suku bunga. Kebijakan suku bunga baru dikeluarkan jika kondisi ekonomi benar-benar harus didukung oleh sector finansial dan kondisi perekonomian yang semakin membaik. The Fed mulai tahun 2009 hingga saat ini tidak merubah kebijakan suku bunga bank sentral sehingga selisih suku bunga berpengaruh tidak signifikan tetapi berarah positif. Artinya penurunan dan peningkat suku bunga yang terjadi belum tentu akan menaikan atau menurunkan nilai tukar, namun apabila dalam kurun waktu penelitian ini terjadi perubahan suku bunga yang signifikan pada periode tertentu akan berarah positif. Apabila terjadi peningkatan suku bunga domestik maka akan menyebabkan Rupiah terdepresiasi karena para investor asing akan menarik kemabali investasi sebitu juga investor domestik akan lebih berinvestasi ke Amerika sehingga terjadi aliran dana keluar ke Indonesia sehingga kurs akan terdepresiasi. Arah positif tersebut tidak sejalan dengan penelitian yang dilakukan oleh Oktavia et.al (2013) yang menyatakan bahwa peningkatan suku bunga domestik akan menyebabkan kurs terapresiasi dimana ketika suku bunga domestic mengalami peningkatan maka masyarakat akan lebih suka menyimpan Rupiah karena dianggap akan memberikan imbalan yang besar begitu juga dengan para invetor asing sehingga terjadi aliran modal masuk ke indonesia. Namun ketidak mampuan secara signifikan tersebut tidak sesuai denga penelitian yang dilakukan oleh Grubacic (2000) dimana terdapat pengaruh yang signifikan antara suku bunga terhadap nilai tukar.

Berdasarkan pernyataan tersebut berarti kebijakan suku bunga yang dilakukan oleh bank sentral yang bertujuan untuk mengendalikan nilai tukar Rupiah dianggap belum dapat atau tidak mampu secara signifikan mempengaruhi perubahan nilai tukar rupiah. Hal tersebut dikarenakan bank sentral Amerika yang kadangkala menggunkan kebijakan yang sama yaitu Fed Fund Rate dalam mengendalikan nilai tukar Dollar terhadap mata uang Negara lain. Dengan melihat hasil tersebut mengindikasikan hasil estimasi tidak sesuai dengan teori yang ada dimana perubahan tingkat suku bunga akan menyebabkan expected return dari investasi keuangan. Artinya semakin tinggi suku bunga suatu Negara akan meningkatkan expected return investasi keuangan sehingga menyebabkan masuknya aliran modal ke dalam negeri dan menimbulkan penguatan terhadap nilai tukar mata uang domestik terhadap mata uang asing (Noor, 2011). Namun dianggap sesuai teori jika suatu Negara mengendalikan nilai tukar dengan mengontrol suku bunga dan dianggap signifikan dalam beberapa kurun waktu karena jika suatu Negara menaikan ataupun menurunkan suku bunga dengan tiba-tiba dan secara langsung mempengaruhi nilai tukar maka teori akan dianggap sesuai dengan penerapannya.
Selisih inflasi Indonesia dan Amerika berpengaruh positif dan signifikan terhadap perubahan kurs Rupiah terhadap Dollar Amerika Serikat. Artianya apabila perbedaan inflasi meningkat akan meningkatkan perubahan kurs Rupiah atas Dollar Amerika Serikat. Apabila Inflasi domestik yang meningkat akan mengakibatkan kurs terdepresiasi sebaliknya apabilai inflasi luar negeri meningkat maka akan mengakibatkan kurs Rupiah terapresiasi karena Inflasi yang tinggi disuatu Negara akan menyulitkan kalkulasi perencanaan bisnis sehingga berdampak buruk bagi aktifitas perekonomian dalam jangka panjang (Pratiwi dan Santoso, 2012). Inflasi yang terjadi mengakibatkan daya beli masyarakat untuk memenuhi kebutuhan semakin rendah karena harga barang dan jasa mengalami kenaikan secara terus menerus dimana ketika harga barang dan jasa yang terus meningkat tersebut akan mengakibatkan impor barang Amerika juga meningkat sehingga permintaan valas Amerika Serikat meningkat. Hal tersebut sejalan dengan penelitian Ghost dan Philips (1998) yang menggunakan data panel dari beberapa Negara yang menyatakan bahwa laju inflasi yang moderat sekalipun dapat berdampak buruk pada proses pertubuhan ekonomi di suatu negara. Di sisi lain kenaikan harga barang di Indonesia akan mengurangi impor AS dari Indonesia sehingga permintaan Rupiah akan menurun. Pengaruh positif tersebut sejalan dengan pernyataan Charles et al dalam Anas (2002:25) yang menyatakan bahwa terdapat hubungan yang positif antara inflasi dan nilai tukar. Penelitian ini juga mendukung penelitian yang dilakukan oleh Grubacic (2002), Coakley dan Fuertes (2000), Noor (2011) dan Oktavia et el (2013) yang menyatakan bahwa terdapat hubungan yang positif signifikan antara inflasi dan nilai tukar. Penelitian ini sesuai dengan teori purchasing power parity (PPP) dimana inflasi yang meningkat atau harga barang-barang luar negeri turun dan harga barang domestik tetap maka barang impor relatif menjadi lebih murah dan permintaannyapun naik sehingga mendorong mata uang domestik menjadi depresiasi.

Pergerakan nilai tukar juga diakibatkan oleh ekspor dan Impor antara kedua Negara yang melakukan perdagangan. Ekspor yang mempunyai pengaruh negatif dan signifikan terhadap nilai tukar Rupiah atas dolar Amerika Serikat berlawanan arah berarti bahwa shock yang terjadi pada ekspor akan direspon negative oleh nilai tukar. Dimana ekspor yang semakin tinggi akan mengakibatkan nilai tukar semakin menurun yaitu terapresiasi. Hal ini tidak sesuai dengan penelitian Djulius dan Nurdiansyah (2014) yang menyatakan bahwa baik dalam jangka pendek maupun jangka panjang peningkatan ekspor akan diikuti oleh pelemahan nilai tukar yaitu mempunyai pengaruh positif terhadap nilai tukar. Berbeda juga dengan penelitian Agustin (2009) yang mengindikasikan bahwa variabel total nilai tukar tidak signifikan terhadao perubahan nilai tukar. Secara teoritis pengaruh ekspor terhadap nilai tukar mempunyai hubungan yang negatif dimana penguatan nilai tukar rupiah dengan semakin tingginya nilai ekspor. Penerimaan dari ekspor barang dan jasa oleh Negara lain yang semakin besar mengakibatkan jumlah valuta asing yang dimiliki suatu Negara semakin besar sehingga nilai tukar Rupiah terhadap Dolar AS cenderung menguat.

Di sisi lain pengaruh selisih impor terhadap nilai tukar positif dan signifikan artinya shock yang terjadi pada impor akan direspon positif oleh nilai tukar. Semakin banyak barang dan 
jasa yang di impor ke Amerika serikat maka akan semakin banyak permintaan valuta asing sehingga kurs akan cenderung meningkat. Penelitiana ini sejalan dengan Djulius dan Nurdiansyah (2014) dimana baik dalam jangka pendek maupun jangka panjang impor mempunyai pengaruh positif signifikan terhadap kurs rupiah begitu juga dengan penelitian Agustin (2009) yang menyatakan bahwa hubungan variabel total nilai impor dan nilai tukar searah atau positif . Nilai impor yang semakin tinggi akan mengakibatkan nilai tukar semakin melemah dimana ekspektasi impor tersebut akan diikuti dengan peningkatan valas yang digunakn untuk membayar barang impor. Hasil penelitian ini dianggap sesuai teori yang ada dimana pertumbuhan impor berarti meningkatkan pembayaran kepada ekportir asing sehingga akan menambah valas asing di dalam negeri yang mengakibatkan nilai tukar rupiah semakin terdepresiasi.

\section{Simpulan}

Pemaparan hasil lebih jelas dapat diambil kesimpulan sebagai berikut:

Berdasarkan analisis kuantitatif dengan menggunakan Parsial Adjustment Model(PAM) metode estimasi Ordinary Least Square (OLS) menyimpulkan bahwa:

a.Secara keseluruhan seluruh variabel bebas mampu menjelaskan variabel terikat dimana variabel bebas secara simultan mempengaruhi besarnya nilai tukar rupiah atas Dolar Amerika sebesar $77,17 \%$ sedangkan sedangkan sisanya dipengaruhi oleh variabel lain di luar model tersebut.

b.Sedangkan secara parsial variabel independen juga dapat menjelaskan varibel dependen. Artinya setiap variabel dapat menjelaskan besarnya nilai tukar, namun terdapat satu variabel yang tidak dapat menjelaskan atau tidak signifikan terhadap besarnya kurs Rupiah terhdap Dolar dan tidak sesuai dengan teori yang ada yaitu variabel suku bunga. Hal itu disebabkan karena Suku bunga yang tidak berfluktuasi pada periode penelitian dan kebijakan suku bunga yang dikeluarkan selalu akan diikuti oleh bank sentral negara lain. Sehingga kebijakan suku bunga belum dapat diterapkan sepenuhnya untuk menentukan besarnya nilai tukar. Variabel lain yang dianggap kuat mempengaruhi besarnya nilai tukar adalah variabel ekspor yang ditandai dengan koefisien varibel yang negative. Artinya semakin tinggi ekspor akan mengakibatkan nilai tukar menurun atau apresiasi.

\section{Referensi}

Anas, Kholidin, 2002, Analisis Faktor-faktor Yang Mempengaruhi Perubahan Nilai Tukar Rupiah Indonesia dan Amerika sebagai Variabel Eksogen. Thesis, Semarang:Universitas Diponegori

Agustin, Grisvia. 2009. Analisis Paritas Daya Beli Pada Kurs Rupiah terhadap Dolar Amerika SErikat Periode September 1997 -Desember 2007 dengan Menggunakan Metode Error Correction Model. Jurnal IESP Vol 1, No, 1; Fakultas Ekonomi Universitas Negeri Malang

Atmadja, Adwin Surya, 2002. Analisis Pergerakan Nilai Tukar Rupiah terhadap Dollar Amerika Serikat Setelah diterapkan Kebijakan Sistem Nilai Tukar mengambang bebas di Indonesia. Journal Akuntansi dan Keuangan Vol 4, No. 1 hal 69-78. Universitas Kristen Petra

Chou, W.L, 2000. Exchange Rate Variability and China's Export. Journal of Comparative Economic, 28:61-79

Coakley and Fuertes, 2000, Short Run Real Exchange Rate Dynamics: Manchester School, Vol 68 No 4

Djulius dan Nurdiansyah. 2014. Keseimbangan Jangka Panjang dan Jangka Pendek Nilai tukar Rupiah terhadap dolar Amerika. Journal Trikonomika Vol 13 No 1. Fakultas Ekonomi Universitas Pasundan Bandung

Ghost and Phillips, 1998. Warning: Inflation May Be Harmful to Your Growth. Journal International Monetary Fund: IMF Staff Papers

Grubacis, Sanja, 2000, Real Rate Determination In Eastern Europe. Atlantis Economic Journal

Indraswanti dan Nurmiati, 2006. Analisis Nilai Tukar Rupiah/Dolar (Aplikasi Model Moneter) Periode 1997-2004. Interest Vol. 16 No. 1: Fakultas Ekonomi UNIB

Kholidin, Anal, 2002. Analisis Faktor-faktor yang mempengaruhi perubahan nilai tukar rupiah Indonesia terhadap Dollar Amerika. Tesis Magister Manajemen Universitas Diponegoro Semarang

Kulkarni, Kishore G. Tanpa Tahun. A Test Purchasing Power Parity (PPP) Theory And International Fisher Effect: A Case of The US Dollar and The Japanese Yen. The Journal of Applied Business Research Vol. 7 No. 1.

Kuspriyadi, Heru, 2004. Analisis Investasi dan faktor-faktor yang mempengaruhinya (Studi Kasus di Jawa Tengah). Master Thesis: Program Pascasarjana Universitas Diponegoro

Krugman, Paul, 2003. Ekonomi Internasional: Teori dan Kebijakan. Jakarta: PT Raja Grafindo Persada

Krugman dan Obdtfeld, 1999. Ekonomi Internasional, Teori dan Kebijakan. Jakarta: PT Raja Grafindo Persada

Magfiroh, Lailatul, 2013. Pengujian teori Efek Fisher International Terhadap nilai Tukar: Studi kasus Indonesia-Jepang, Skripsi Fakultas Ekonomi, Universitas Jember

Messed and Rogoff, 1983, Empirical Exchange Rate Models of the Seventies. Journal of International Economics 4, 3-24: North Holland Publishing Company

Muklis, Imam, 2013, Analisis Volatilitas nilai tukar mata uang Rupiah Terhadap Dolar. Journal of Indonesia Applied Economics. Vol.5 No.2 Hal 172-182: Fakultas Ekonomi Universitas Negeri Malang

Noor, Zulki Zulkifli, 2011. Pengaruh Inflais, Suku Bunga dan Jumlah Uang Beredar terhadap Nilai Tukar. Bandung: Jurnal Trikonomika Vol 10. No. 2 hal 139-147

Nurqoidah, Yusifa. 2010. Analisis Variabel Fundamental dan Variabel Makroekonomi terhadap Eksposur Ekonomi (Studi Perusahaan Tekstil yang Terdaftar di Bursa Efek Indonesia. Tesis Universitas Brawijaya

Oktavia et. al, 2013, Analisis Kurs dan Money Supply di Indonesia, Jurnal kajian Ekonomi,Vol.1 No. 02

Pratiwi dan Santoso, 2012, Analisis Perilaku Kurs Rupiah (IDR) Terhadap Dollar Amerika(USD) pada Sostem Kurs Mengambang Bebas di Indonesia Periode 1997.3-2011.4 (Aplikasi pendekatan Keynesian Sticky Price Model). Diponegoro Journal of Economics Vol 1. No.1. Hal.3

\section{Internet}

World Bank. 2015. Statistik Data. http://www.worldbank.org/

Bank Indonesia. 2015. Statistik Ekonomi Keuangan Indonesia http://www.bi.go.id/ 